\title{
Sociodemographic and health profile of TB/HIV co-infection in Brazil: a systematic review
}

\author{
Perfil Sociodemográfico e de saúde da coinfecção tuberculose/HIV no Brasil: revisão sistemática \\ Perfil Sociodemográfico y de salud de la coinfección tuberculosis/VIH en Brasil: revisión sistemática
}

\section{Shyrlaine Honda Bastos' \\ ORCID: 0000-0003-1674-0823 \\ Mônica Taminato' \\ ORCID: 0000-0003-4075-2496}

Hugo Fernandes'

ORCID: 0000-0003-2380-2914

Tânia Maria Ribeiro Monteiro de Figueiredo" ORCID: 0000-0001-6197-2936

Lúcia Yasuko Izumi Nichiata"'

ORCID: 0000-0001-6515-4404

Paula Hino'

ORCID: 0000-0002-1408-196X

'Universidade Federal de São Paulo. São Paulo, São Paulo, Brazil.

"Universidade Estadual da Paraíba.

Campina Grande, Paraíba, Brazil.

I'Universidade de São Paulo. São Paulo, São Paulo, Brazil.

How to cite this article: Bastos SH, Taminato M, Fernandes H, Figueiredo TMRM, Nichiata LYI, Izumi LY, et al. Sociodemographic and health profile of TB/HIV co-infection in Brazil: a systematic review. Rev Bras Enferm. 2019;72(5):1389-96. doi: http://dx.doi.org/10.1590/0034-7167-2018-0285

\section{Corresponding Author: \\ Shyrlaine Honda Bastos \\ E-mail: shyrlainehonda@gmail.com}

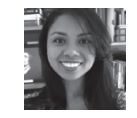

Submission: $05-10-2018$

Approval: 11-29-2018

\begin{abstract}
Objective: to ascertain the epidemiological profile of TB/HIV co-infection in Brazilian scenarios. Method: this is a systematic review conducted via electronic search in databases PubMed, EMBASE, LILACS and SciELO, having as inclusion criterion articles based on the Brazilian scenario of TB/HIV co-infection. Results: of the total 174 studies, 15 were selected, revealing the epidemiological profile of the co-infection in different scenarios: male, economically active age, low education level, brown/black ethnicity, low income, heterosexual, pulmonary clinical form, alcoholism and Directly Observed Therapy. Conclusion: the sociodemographic and epidemiological profile of people with TB/HIV co-infection has an expected occurrence pattern, which corroborates articles found in the literature, either at national level or by grouping the studies according to region or state.

Descriptors: Tuberculosis; Acquired Immunodeficiency Syndrome; Co-infection; Community Health Nursing; Public Health.
\end{abstract}

\section{RESUMO}

Objetivo: conhecer como se apresenta o perfil epidemiológico da coinfecção tuberculose/ HIV em cenários brasileiros. Método: trata-se de uma revisão sistemática realizada por meio de busca eletrônica nos bancos de dados PubMed, EMBASE, LILACS e SciELO, tendo como critério de inclusão artigos de base nacional sobre a coinfecção tuberculose/ HIV. Resultados: do total de 174 estudos, 15 foram selecionados, revelando o perfil epidemiológico da coinfecção em diferentes cenários brasileiros: sexo masculino, idade economicamente ativa, baixa escolaridade, cor parda/negra, baixa renda, heterossexual, forma clínica pulmonar, alcoolismo e realização de Tratamento Diretamente Observado. Conclusão: o perfil sociodemográfico e epidemiológico de pessoas que apresentam a coinfecção TB/HIV possui um padrão de ocorrência esperado, que corrobora com achados da literatura, seja em nível nacional ou por agrupamento dos estudos por região ou estado. Descritores: Tuberculose; Síndrome da Imunodeficiência Adquirida; Coinfecção; Enfermagem em Saúde Comunitária; Saúde Pública.

\section{RESUMEN}

Objetivo: conocer la manera en que se presenta el perfil epidemiológico de la coinfección tuberculosis/VIH en escenarios brasileños. Método: se trata de una revisión sistemática realizada por medio de búsqueda electrónica en las bases de datos PubMed, EMBASE, LILACS y SCiELO, y tiene como criterio de inclusión artículos de base nacional sobre la coinfección tuberculosis/VIH. Resultados: de un total de 174 estudios, se seleccionaron 15 que revelan el perfil epidemiológico de la coinfección en diferentes escenarios brasileños: sexo masculino, edad económicamente activa, baja escolaridad, color de piel pardo/negro, baja renta, heterosexual, forma clínica pulmonar, alcoholismo y realización de Tratamiento Directamente Observado. Conclusión: el perfil sociodemográfico y epidemiológico de personas que presentan la coinfección TB/VIH tiene un estándar de incidencia esperado, corroborado por hallazgos en la literatura, ya sea en el ámbito nacional o por agrupamiento de los estudios por región o estado.

Descriptores: Tuberculosis; Síndrome de la Inmunodeficiencia Adquirida; Coinfección; Enfermería en Salud Comunitaria; Salud Pública. 


\section{INTRODUCTION}

Tuberculosis (TB) is an infectious disease caused by Mycobacterium tuberculosis that is most likely to affect people with HIV/Aids who are malnourished, diabetic, users of tobacco and alcohol. It represents a public health problem, being the ninth most common cause of death in the world, causing thousands of people to become ill and die due to the disease and its complications $^{(1-2)}$. In 2015, Brazil was among the 22 countries with the highest rates of the disease in the world, occupying the 20th position. Despite being a disease with mechanisms that allow its prevention, easy to diagnose and which may be cured in almost all cases, its incidence remains high. Each year, approximately 69,000 new cases are reported, 4,500 deaths having TB as root cause and 6,800 people suffering from TB/HIV co-infection ${ }^{(2)}$.

A global movement for the reduction of the disease's mortality rates was organized in 2014 by the World Health Assembly. It is expected that from 2020 to 2030, every five years, rates decrease by 35,75 and $90 \%$, respectively, compared to data from 2015 , and that TB incidence rates correspond to 20, 50 and 80\%. In Brazil, the General Coordination of the National Tuberculosis Control Program reinforces the importance of achieving this objective within the framework of the Sustainable Development Goals, grounded on prevention, integrated care focused on the patient, health policies and support system, in addition to researches on TB control ${ }^{(1)}$.

Reaching these goals means considering the magnitude of TB in relation to HIV. The risk of a person with HIV/Aids developing active TB is 26 times higher compared to people without HIV/ Aids $^{(3)}$. In global terms, 2016 data showed that $57 \%$ of people with TB were also infected with HIV. However, people who have been recently infected by the latter are at a lower risk of infection by the former than those who have been infected for more than one year ${ }^{(1)}$. The re-emergence of the Aids epidemic in Brazil is currently under discussion, since data reveal that the disease has been showing the worst indicators of the last 30 years, with an increase in cases among homosexuals, accumulation of cases in urban centers and increased male/female ratio. Mortality rates started growing again, the occurrence of 12,700 deaths by the illness having been observed in 2013, a number that is similar to the one registered at the time of implementation of the AntiRetroviral Therapy (ART) $)^{(4)}$.

In 2016, Brazil was on the list of the 30 countries with the highest TB/HIV rates, and only $50 \%$ of coinfected patients had already started ART, even though the World Health Organization (WHO) recommends that ART is initiated eight weeks after the treatment of $\mathrm{TB}^{(1)}$.

The rates of mortality by TB/HIV in the country (2000-2011) were higher among black males, in the economically active age range and residents of the country's southern region. However, a decrease in mortality happened heterogeneously between Brazilian regions, which may be related to the use of ART and to the updating of the protocols used in the co-infection's clinical management ${ }^{(5)}$.

Thus, TB/HIV co-infection is the cause with greatest impact on mortality, and it is therefore necessary that both are managed in an articulated and comprehensive manner, it being the shared responsibility of control programs to minimize their occurrence ${ }^{(6)}$, focusing on strategies for the co-infection's control, such as the early diagnosis of both diseases and ensuring proper treatment in a timely fashion ${ }^{(7)}$.

The importance of knowing the epidemiological profile of TB/ HIV co-infection beyond the mortality issue is emphasized, to give visibility to the occurrence of TB in people living with HIV/Aids and, thus, provide subsidies to improve the control policies of both diseases.

Systematic reviews on this subject for the Brazilian context were not found in the literature, despite the relevance of this topic in an extensive country such as ours, with numerous health-related characteristics and realities, one of which is TB/HIV co-infection.

\section{OBJECTIVE}

To ascertain the epidemiological profile of co-infection published in scientific articles based on the Brazilian scenario over the past ten years (2008-2017).

\section{METHOD}

\section{Ethical aspects}

This study was not submitted to the Research Ethics Committee for being a systematic review.

\section{Study design, location, and period}

This systematic review aimed to select articles published in the Brazilian literature of the last ten years, covering the period between 2008 and 2017.

\section{Population or sample and inclusion and exclusion criteria}

To achieve the proposed objective, the following guiding question was defined: What is (are) the scenario(s) of TB/HIV co-infection in Brazil? The studies were identified via electronic search in databases PubMed, EMBASE, LILACS, SciELO and via manual search of published and identified reviews.

The keywords used in the search strategy were:

("hiv"[MeSH Terms] OR "hiv"[All Fields]) AND ("coinfection"[MeSH Terms] OR "coinfection"[All Fields] OR ("co"[All Fields] AND"infection"[All Fields]) OR"co infection"[All Fields]) AND ("tuberculosis"[MeSH Terms] OR"tuberculosis"[All Fields]) AND ("brazil"[MeSH Terms] OR "brazil"[All Fields]) AND ("epidemiology"[MeSH Terms] OR "epidemiology"[All Fields] OR "epidemiological"[All Fields]).

As inclusion criteria, articles that presented a description of the epidemiological profile of patients coinfected with TB/HIV in the Brazilian scenario were selected, independent of language.

The exclusion criteria encompassed studies that had not been published in Brazilian journals, studies on multidrugresistant tuberculosis, with children or that did not address TB/ HIV co-infection. 
The studies were evaluated based on title and summary and analyzed according to the inclusion and exclusion criteria by two independent reviewers. In case of doubt or disagreement, a third reviewer was consulted. All selected studies were read in their entirety.

\section{Study protocol}

This systematic review was based on the review protocols established by the Cochrane Collaboration ${ }^{(8)}$ to obtain the best available evidence for the theme chosen.

\section{Analysis of the results}

Methodological quality is defined as the guarantee that the studies' design and findings are free of biases. The instrument used for evaluation of the observational studies was the Strengthening the Reporting of Observational Studies in Epidemiology (Strobe) statement. Thus, based on Strobe's recommendations, the evaluation was classified in $\mathrm{A}$ (studies that met a value equal to or greater than $80 \%$ of the criteria); $B$ (studies that met 50 to $80 \%$ of the criteria) and C (studies that met less than $50 \%$ of the criteria) ${ }^{(8)}$.

\section{RESULTS}

Based on the criteria established for the systematic review, 174 studies were found, 103 from PubMed, 27 from EMBASE, 27 from LILACS and 17 from SciELO. In a pre-selection, 32 studies were identified, 15 of them having been selected (Figure 1).

The 15 selected studies are described in Chart 1 with the following items: bibliographic reference, scenario, study design, sociodemographic profile, clinical features and outcome and Strobe.
Studies identified via electronic and manual search $=174$

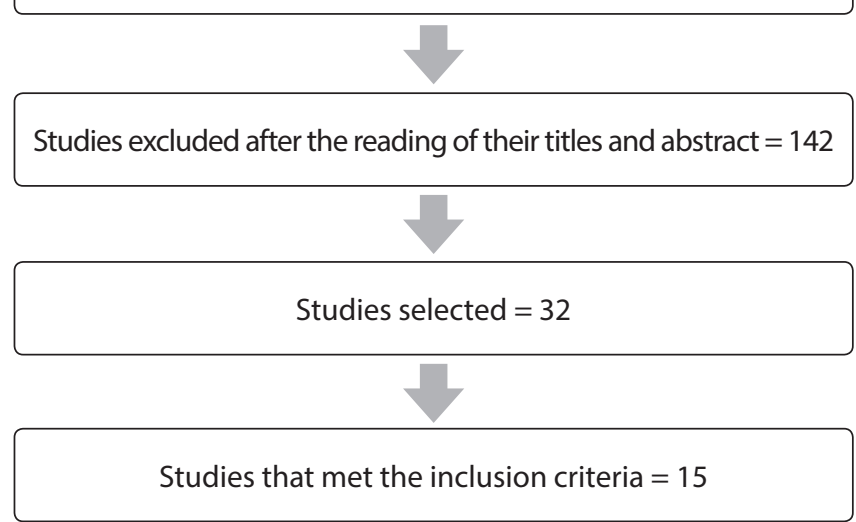

Figure 1 - Flowchart of the studies' selection and identification

The analysis of the articles comprising this investigation showed greater distribution of the studies in the Northeastern region, with five articles: two in Recife ${ }^{(9-10)}$, one in Fortaleza ${ }^{(11)}$, one in Maranhão ${ }^{(12)}$ and one covering the Northeastern states ${ }^{(13)}$. The Southeast region accounted for four studies, two in São José do Rio Preto ${ }^{(14-15)}$, one in Ribeirão Preto ${ }^{(16)}$ and one in an administrative district of São Paulo ${ }^{(17)}$. Next, four studies that covered the entire national territory were identified ${ }^{(5,18-20)}$, and finally, two articles in the Northern region, one in the state of Amazonas ${ }^{(21)}$ and one in the capital Manaus ${ }^{(22)}$. No studies conducted in the Southern and Central-Western regions of Brazil were found.

As for the studies' design, all are observational, and six are of the cross-sectional type ${ }^{(5,17,19-21,22)}$. Five cohort studies ${ }^{(9,10,12-14)}$, three ecological studies ${ }^{(15-16,18)}$ and one control case ${ }^{(11)}$ were identified.

Chart 1 - Summary of the characteristics of the studies included

\begin{tabular}{|c|c|c|c|c|c|}
\hline Citation & $\begin{array}{l}\text { Study } \\
\text { scenario }\end{array}$ & $\begin{array}{l}\text { Study } \\
\text { design }\end{array}$ & Sociodemographic profile & $\begin{array}{l}\text { Clinical features } \\
\text { and outcome }\end{array}$ & Strobe \\
\hline $\begin{array}{l}\text { Domingos MP, Caiaffa WT, Colosimo EA. } \\
\text { Mortalidade, co-infecção por HIV/AIDS e } \\
\text { abandono do tratamento como fatores } \\
\text { prognósticos para tuberculose em Recife, } \\
\text { Pernambuco, Brasil. Cad Saúde Pública 2008; } \\
\text { 24(4):887-96 } \\
\end{array}$ & Recife & $\begin{array}{l}\text { Cohort (from } \\
\text { January 1, } 1996 \\
\text { to December } 31 \text {, } \\
\text { 2000) }\end{array}$ & $\begin{array}{l}\text { Males aged from } 40 \text { to } 49 \\
\text { years old. }\end{array}$ & $\begin{array}{l}\text { Mixed form, age }>50 \\
\text { years old associated } \\
\text { with death. }\end{array}$ & A \\
\hline $\begin{array}{l}\text { Maruza M, Ximenes RAA, Lacerda HR. Desfecho } \\
\text { do tratamento e confirmação laboratorial do } \\
\text { diagnóstico de tuberculose em pacientes com } \\
\text { HIV/AIDS no Recife, Pernambuco, Brasil. J Bras } \\
\text { Pneumol 2008;34(6):394-403(10) }\end{array}$ & Recife & $\begin{array}{l}\text { Cohort (July } 2002 \\
\text { to June 2004) }\end{array}$ & $\begin{array}{l}\text { Males with mean age } \\
\text { corresponding to } 36 \text { years } \\
\text { old. }\end{array}$ & $\begin{array}{l}\text { Pulmonary form, } \\
\text { cure }(56.1 \%) \text {, } \\
\text { abandonment of } \\
\text { treatment }(11.5 \%) \text {, } \\
\text { death }(29 \%) .\end{array}$ & A \\
\hline $\begin{array}{l}\text { Carvalho BM, Monteiro AJ, Pires Neto R da J, } \\
\text { Grangeiro TB, Frota CC. Fatores relacionados } \\
\text { à coinfecção HIV/tuberculose em um hospital } \\
\text { brasileiro de referência. Braz J Infect Dis } \\
2008 ; 12(4): 281-6^{(11)}\end{array}$ & Fortaleza & $\begin{array}{l}\text { Case-control } \\
\text { (January } 2004 \text { to } \\
\text { December 2005) }\end{array}$ & $\begin{array}{l}\text { Males aged between } 41 \text { and } \\
45 \text { years old with less than } 8 \\
\text { years of education. }\end{array}$ & $\begin{array}{l}\text { Alcohol and smoking } \\
\text { not related to TB, } \\
\text { number of CD4 cells/ } \\
\mu \mathrm{l}<200 \text {. }\end{array}$ & B \\
\hline $\begin{array}{l}\text { Santos-Neto M, Silva FL, Sousa KR, Yamamura } \\
\text { M, Popolin MP, Arcêncio RA. Perfil clínico e } \\
\text { epidemiológico e prevalência da coinfecção } \\
\text { tuberculose/HIV em uma regional de saúde no } \\
\text { Maranhão. J Bras Pneumol 2012;38(6):724-32 }{ }^{(12)}\end{array}$ & Maranhão & $\begin{array}{l}\text { Cohort (January } \\
2001 \text { to } \\
\text { December 2010) }\end{array}$ & $\begin{array}{l}\text { Males aged from } 20 \text { to } 40 \\
\text { years old, mixed ethnicity, } \\
\text { up to } 4 \text { years of education, } \\
\text { urban residence. }\end{array}$ & $\begin{array}{l}\text { Pulmonary form, DOT } \\
(57 \%) \text {, cure }(62 \%) \text {. }\end{array}$ & B \\
\hline $\begin{array}{l}\text { Barbosa IR, Costa ICC. Estudo epidemiológico } \\
\text { da coinfecção tuberculose-HIV no nordeste do } \\
\text { Brasil. Rev Patol Trop 2014;43(1):27-38 }\end{array}$ & $\begin{array}{c}\text { Northeastern } \\
\text { States }\end{array}$ & $\begin{array}{l}\text { Cohort (2002 to } \\
\text { 2011) }\end{array}$ & $\begin{array}{l}\text { Males aged from } 15 \text { to } 39 \\
\text { years old, Pernambuco having } \\
\text { shown the highest co- } \\
\text { infection rate. }\end{array}$ & $\begin{array}{l}\text { Pulmonary clinical } \\
\text { form, cure }(39 \%), 8.9 \% \\
\text { lethality rate. }\end{array}$ & B \\
\hline
\end{tabular}


Chart 1 (concluded)

\begin{tabular}{|c|c|c|c|c|c|}
\hline Citation & $\begin{array}{l}\text { Study } \\
\text { scenario }\end{array}$ & $\begin{array}{l}\text { Study } \\
\text { design }\end{array}$ & Sociodemographic profile & $\begin{array}{l}\text { Clinical features } \\
\text { and outcome }\end{array}$ & Strobe \\
\hline $\begin{array}{l}\text { Santos ML, Ponce MA, Vendramini SH, Villa TC, } \\
\text { Santos NS, Wysocki AD, Kuyumijian FG, Gazetta } \\
\text { CE. A dimensão epidemiológica da coinfecção } \\
\text { TB/HIV. Rev Latino-am Enfermagem 2009; } \\
\text { 17(5):683-8 }\end{array}$ & $\begin{array}{l}\text { Sao Jose do } \\
\text { Rio Preto }\end{array}$ & $\begin{array}{l}\text { Cohort (from } \\
\text { January } 1998 \text { to } \\
\text { December } 31 \\
\text { 2006) }\end{array}$ & $\begin{array}{l}\text { Males aged from } 20 \text { to } 59 \\
\text { years old, most of whom did } \\
\text { not finish elementary school. }\end{array}$ & $\begin{array}{l}\text { Pulmonary form, DOT } \\
(46 \%), \text { cure outcome } \\
(33 \%) \text { followed by } \\
\text { death ( } 14.3 \%) \text { and no } \\
\text { cases of abandonment } \\
\text { of treatment. }\end{array}$ & B \\
\hline $\begin{array}{l}\text { Vendramini SH, Santos NS, Santos Mde L, } \\
\text { Chiaravalloti-Neto F, Ponce MA, Gazetta CE, } \\
\text { Villa TCS, Ruffino-Netto A. Análise espacial da } \\
\text { co-infecção tuberculose/HIV: relação com níveis } \\
\text { socioeconômicos em município do sudeste do } \\
\text { Brasil. Rev Soc Bras Med Trop 2010;43(5):536-41 }\end{array}$ & $\begin{array}{l}\text { Sao Jose do } \\
\text { Rio Preto }\end{array}$ & Ecological & $\begin{array}{l}\text { Up to } 3 \text { years of education, } \\
\text { income of } 2 \text { to } 3 \text { minimum } \\
\text { wages, association of the } \\
\text { rate of co-infection with } \\
\text { population from the lower } \\
\text { classes. }\end{array}$ & Data not found. & B \\
\hline $\begin{array}{l}\text { Brunello ME, Chiaravalloti-Neto F, Arcêncio RA, } \\
\text { Andrade RL, Magnabosco GT, Villa TC. Áreas } \\
\text { de vulnerabilidade para co-infecção HIV-aids/ } \\
\text { TB em Ribeirão Preto, SP. Rev Saúde Pública } \\
\text { 2011;45(3):556-63(16) }\end{array}$ & Ribeirão Preto & Ecological & $\begin{array}{l}\text { Males aged from } 20 \text { to } 39 \\
\text { years old, with } 4 \text { to } 7 \text { years of } \\
\text { education, an intermediate } \\
\text { and lower socioeconomic } \\
\text { status being associated with } \\
\text { higher incidence rates. }\end{array}$ & $\begin{array}{l}\text { Pulmonary clinical } \\
\text { form, supervised } \\
\text { treatment }(48 \%) \text {, cure } \\
(48 \%) \text {, abandonment } \\
(4.2 \%) \text {, death not } \\
\text { related to TB }(25 \%) \text {. }\end{array}$ & $B$ \\
\hline $\begin{array}{l}\text { Hino P, Takahashi RF, Bertolozzi MR, Egry } \\
\text { EY. Coinfecção de TB/HIV em um distrito } \\
\text { administrativo do Município de São Paulo. } \\
\text { Acta Paul Enferm 2012;25(5):755-61(17) }\end{array}$ & São Paulo & Cross-sectional & $\begin{array}{l}\text { Males aged from } 30 \text { to } 39 \\
\text { years old, with } 4 \text { to } 7 \text { years of } \\
\text { education. }\end{array}$ & $\begin{array}{l}\text { Pulmonary clinical } \\
\text { form, self-administered } \\
\text { treatment }(48.8 \%), \text { DOT } \\
(34.6 \%), \text { cure }(47.5 \%) \\
\text { and abandonment of } \\
\text { treatment }(13 \%) .\end{array}$ & B \\
\hline $\begin{array}{l}\text { Rodrigues-Júnior AL, Ruffino-Netto A, de } \\
\text { Castilho EA. Distribuição espacial do índice de } \\
\text { desenvolvimento humano, da infecção pelo } \\
\text { HIV e da comorbidade AIDS-tuberculose: Brasil, } \\
\text { 1982-2007. Rev Bras Epidemiol 2014;17(Suppl } \\
\text { DSS):204-15(18) }\end{array}$ & Brasil & Ecological & $\begin{array}{l}\text { Males aged from } 20 \text { to } 34 \\
\text { years old, heterosexual, the } \\
\text { higher rates found in the } \\
\text { Southeast and South being } \\
\text { associated with the high HDI } \\
\text { of these regions up to } 1997 \\
\text { and its decline after } 1998 .\end{array}$ & Data not found. & B \\
\hline $\begin{array}{l}\text { Gaspar RS, Nunes N, Nunes M, Rodrigues VP. } \\
\text { Análise temporal dos casos notificados de } \\
\text { tuberculose e de coinfecção tuberculose HIV } \\
\text { na população brasileira no período entre } 2002 \\
\text { e } 2012 \text {. J Bras Pneumol 2016;42(6):416-22 }\end{array}$ & Brasil & Cross-sectional & $\begin{array}{l}\text { Males, although higher } \\
\text { incidence was found in } \\
\text { women; reduction in the age } \\
\text { group from } 0 \text { to } 9 \text { years old, and } \\
\text { increase in other age ranges, } \\
\text { especially for those over } 60 \\
\text { years old; increased incidence } \\
\text { in the North, Northeast and } \\
\text { Midwest regions, decrease in } \\
\text { the Southeast region. }\end{array}$ & $\begin{array}{l}\text { Lower chance of cure } \\
(50.7 \%) \text { in relation } \\
\text { to individuals with } \\
\text { TB only }(71.1 \%) \text {, } \\
\text { increased rate of } \\
\text { abandonment of } \\
\text { treatment }(13.6 \%) \\
\text { and greater chance of } \\
\text { death }(3.6 \%) \text {. }\end{array}$ & B \\
\hline $\begin{array}{l}\text { Prado TN, Rajan JV, Miranda AE, Dias ED, Cosme } \\
\text { LB, Possuelo LG, Sanchez MN, Golub JE, Riley } \\
\text { LW, Maciel EL. Clinical and epidemiological } \\
\text { characteristics associated with unfavorable } \\
\text { tuberculosis treatment outcomes in TB-HIV } \\
\text { co-infected patients in Brazil: a hierarchical } \\
\text { polytomous analysis. Braz J Infect Dis } \\
\text { 2017;21(2):162-70(20) }\end{array}$ & Brasil & Cross-sectional & $\begin{array}{l}\text { Males aged from } 20 \text { to } 59 \\
\text { years old, with } 4 \text { to } 7 \text { years of } \\
\text { education. }\end{array}$ & $\begin{array}{l}\text { Alcoholism, pulmonary } \\
\text { form, higher rate of } \\
\text { death among black } \\
\text { and mixed-race } \\
\text { individuals, and for } \\
\text { those over } 60 \text { years old. }\end{array}$ & B \\
\hline $\begin{array}{l}\text { Lima MD, Martins-Melo FR, Heukelbach J, Alencar } \\
\text { CH, Boigny RN, Ramos-Júnior AN. Mortalidade } \\
\text { relacionada à coinfecção tuberculose e HIV/AIDS } \\
\text { no Brasil, 2000-2011: padrões epidemiológicos } \\
\text { e tendências temporais. Cad. Saúde Pública } \\
\text { 2016;32(10):1-11 }\end{array}$ & Brasil & Cross-sectional & $\begin{array}{l}\text { Single males aged from } 30 \text { to } \\
39 \text { years old, black, with } 4 \text { to } \\
7 \text { years of education. }\end{array}$ & $\begin{array}{l}\text { Greater mortality of } \\
\text { individuals residing } \\
\text { in the South and } \\
\text { Southeast regions. }\end{array}$ & $A$ \\
\hline $\begin{array}{l}\text { Magno EDS, Saraceni V, Souza AB, Magno } \\
\text { RDS, Saraiva MDGG, Buhrer-Sékula S. Fatores } \\
\text { associados à coinfecção tuberculose e HIV: } \\
\text { o que apontam os dados de notificação do } \\
\text { Amazonas, Brasil, 2001- 2012. Cad. Saúde } \\
\text { Pública 2017; 33(5):e00019315 (21) }\end{array}$ & Amazonas & Cross-sectional & $\begin{array}{l}\text { Mixed race, heterosexual } \\
\text { males aged from } 25 \text { to } 39 \\
\text { years old, residing in the } \\
\text { capital. }\end{array}$ & $\begin{array}{l}\text { Pulmonary form. } \\
\text { Death (30.9\%). }\end{array}$ & $A$ \\
\hline $\begin{array}{l}\text { Oliveira NF, Gonçalves MJ. Fatores sociais e } \\
\text { ambientais associados à hospitalização de } \\
\text { pacientes com tuberculose. Rev. Latino-Am. } \\
\text { Enfermagem 2013;21(2):507-14(22) }\end{array}$ & Manaus & Cross-sectional & $\begin{array}{l}\text { Males aged from } 20 \text { to } 29 \\
\text { years old, with } 4 \text { to } 10 \text { years } \\
\text { of education, who did not } \\
\text { own a house and lived in a } \\
\text { masonry, working with daily } \\
\text { garbage collection. }\end{array}$ & $\begin{array}{l}\text { Use of alcohol } \\
(50.8 \%) \text {. }\end{array}$ & B \\
\hline
\end{tabular}


Chart 2 - Comparison of the epidemiological profile and clinical characteristics in Brazilian scenarios

\begin{tabular}{|c|c|c|c|c|c|c|c|c|c|c|c|c|}
\hline Scenario & Sex & $\begin{array}{c}\text { Age } \\
\text { (years) }\end{array}$ & $\begin{array}{c}\text { Education } \\
\text { level } \\
\text { (years) }\end{array}$ & Ethnicity & $\begin{array}{c}\text { Sexual } \\
\text { orientation }\end{array}$ & $\begin{array}{c}\text { Socioeconomic } \\
\text { level }\end{array}$ & $\begin{array}{c}\text { Clinical TB } \\
\text { manifestation }\end{array}$ & $\begin{array}{c}\text { Alcohol/ } \\
\text { Tobacco } \\
(\%)\end{array}$ & $\begin{array}{c}\text { Type of } \\
\text { treatment } \\
(\%)\end{array}$ & $\begin{array}{c}\text { Cure } \\
(\%)\end{array}$ & $\begin{array}{c}\text { Abandonment } \\
(\%)\end{array}$ & $\begin{array}{c}\text { Death } \\
(\%)\end{array}$ \\
\hline Brasil & $\begin{array}{l}\text { Male/ } \\
\text { fem }\end{array}$ & $20->60$ & 4-7 & Black & Heterosexual & L & Pulmonary & Alcohol & 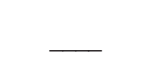 & 50.7 & 13.6 & 3.6 \\
\hline Northeast & Male & $15-49$ & Up to 8 & $\begin{array}{l}\text { Mixed } \\
\text { race }\end{array}$ & & & $\begin{array}{l}\text { Pulmonary/ } \\
\text { Mixed }\end{array}$ & $\begin{array}{l}\text { Non- } \\
\text { related }\end{array}$ & DOT 57 & $39-62$ & 11.5 & $8.9-29$ \\
\hline Southeast & Male & $20-59$ & $3-7$ & 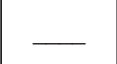 & $\underline{ }$ & Low & Pulmonary & 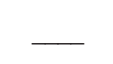 & $\begin{array}{l}\text { DOT (34.6 - } \\
48), \text { AT }(48.8)\end{array}$ & $33-48$ & $0-13$ & $14.3-25$ \\
\hline North & Male & $20-39$ & $4-10$ & $\begin{array}{l}\text { Mixed } \\
\text { race }\end{array}$ & Heterosexual & Low & Pulmonary & $\begin{array}{l}\text { Alcohol } \\
50.8\end{array}$ & & & & 30.9 \\
\hline
\end{tabular}

The studies set in Brazil ${ }^{(5,18-20)}$ presented a profile with male prevalence; however, one study showed higher incidence of TB/ HIV co-infection in females ${ }^{(19)}$. Ages ranged from 20 to 60 years old. Other factors found were heterosexuality, single marital status and having four to seven years of education, as well as higher rates of TB/HIV co-infection in the South and Southeast of Brazil until 1997, followed by higher rates in the North and Northeast of the country for the period between 2000 and $2011^{(5)}$. The clinical characteristics found in this scenario revealed predominance of the pulmonary clinical form of TB and the co-infection's association with alcoholism ${ }^{(20)}$. It was observed that the percentage of cure for co-infected patients was lower when compared to those with TB only ( $50.7 \%$ and $71.1 \%$, respectively), the percentage of abandonment having corresponded to $13.6 \%$. There was higher mortality among black and mixed-race individuals residing in the South and Southeast regions, and mortality rates were higher among co-infected patients (3.6\%) when compared to those with TB only $(1.9 \%)^{(19)}$.

The epidemiological profile of the Northeast region ${ }^{(9-10,12-13)}$ showed the prevalence of mixed-race males aged from 15 to 49 years old, with up to eight years of education ${ }^{(11-12)}$ and urban residence ${ }^{(12)}$. One of the studies ${ }^{(13)}$ indicated that the state of Pernambuco showed the highest rate of TB/HIV co-infection. The clinical characteristics showed prevalence of the pulmonary form of $\mathrm{TB}^{(10,12-13)}$, although mixed-form cases were also reported ${ }^{(9)}$. The adherence to Directly Observed Therapy (DOT) was 57\%(12). Alcoholism and smoking showed no relationship with TB in one of the studies found ${ }^{(11)}$ and CD4 T cells were below 200 cells/ $\mu$ l. The chance of cure for co-infected patients varied from 39 to $62 \%$ in the studies ${ }^{(10,12-13)}$. The rate of abandonment of TB treatment was $11.5 \%^{(10)}$. Mortality was related to individuals over the age of 50 years old ${ }^{(9)}$, with rates ranging from 8.9 to $29 \%{ }^{(10,13)}$.

In the scenarios of a municipality of the state of São Paulo and in an administrative district of the capital ${ }^{(14-17)}$, the epidemiological profile found was: prevalence of males aged from 20 to 59 years old $^{(14,16-17)}$, with three to seven years of education ${ }^{(15-17)}$ or who had not finished elementary school ${ }^{(14)}$, with income ranging from two to three minimum wages ${ }^{(15)}$ or whose socioeconomic level was low ${ }^{(16)}$. One of the studies indicated the north region of São José do Rio Preto as having the highest prevalence of cases of TB/HIV co-infection ${ }^{(15)}$. In relation to clinical characteristics, the pulmonary clinical form of TB was observed, DOT adherence ranged from $46^{(14)}$ to $48 \%{ }^{(16-17)}$ and the rate of self-administered treatment was $48.8 \%{ }^{(17)}$. Treatment outcome ranged from $33^{(14)}$ to $48 \%{ }^{(16-17)}$ in relation to cure. The rate of abandonment of treatment ranged from zero ${ }^{(14)}$ to $13 \%^{(16-17)}$, while mortality rate was $14.3 \%^{(14)}$ among coinfected patients and $25 \%^{(16)}$ for deaths not associated with TB.

The epidemiological profile of the Northern region for patients co-infected with TB/HIV ${ }^{(21-22)}$ showed prevalence of males aged from 20 to 39 years old, with four to 10 years of education ${ }^{(22)}$, mixed race, heterosexual, residing in the capital and with low socioeconomic level. The clinical characteristics revealed prevalence of the pulmonary form of $\mathrm{TB}^{(21)}$ and relationship with the use of alcohol corresponding to $50.8 \%{ }^{(22)}$. Mortality rate was $30.9 \%^{(21)}$ (Chart 2).

The majority of the studies obtained classification $\mathrm{B}^{(11-20,22)}$ according to the Strobe Statement, losing points mainly for omitting details of the methods and results of the studies. The other studies ${ }^{(5,9-10,21)}$ were classified as A, although they did not obtain a $100 \%$ score for the criteria evaluated.

\section{DISCUSSION}

Given the importance of TB/HIV coinfection as a public health problem in Brazil, this unprecedented systematic review with metaanalysis was performed, with support from the Department of Collective Health of a public university and the Brazilian Cochrane Center.

The analysis of the results found in this review identified prevalence of studies based on sociodemographic data, either at national level or by grouping the studies according to region or state. It was possible to observe that characteristics such as male sex, economically active age, low education level and heterosexuality were associated with TB/HIV co-infection. One study ${ }^{(19)}$, with national scope, indicated the increased incidence of co-infection among females, for the period from 2002 to 2012, although the reason for this increase is unknown. However, in the last ten years (from 2006 to 2016), a decline in the detection of Aids among women was identified in almost all age groups, with the exception of the range between 15 and 19 years old (from 3.6 to $4.1 \%$ ) and in those aged over 60 (from 5.6 to $5.4 \%)^{(23)}$.

Heterosexuality was singled out as a feature associated with co-infection, the rate of co-infected patients having been lower among homosexuals in the selected studies ${ }^{(18,21)}$. A cross-sectional study ${ }^{(24)}$, held in São Paulo in 2014 with 124 individuals (58 crossdressers and 66 transsexual individuals), argued that despite the increased visibility of this population, studies on this group are 
still scarce. Indeed, most of the studies selected have an epidemiological design, with secondary data having been collected from the Health Information System (Sinan), in which the sexuality field in the TB and HIV/Aids notification files contains only the options male, female, or ignored, causing difficulty in obtaining more accurate data regarding sexuality.

A research in Fortaleza identified social and economic aspects and lifestyles as barriers for adherence to treatment in patients with TB/HIV co-infection ${ }^{(25)}$. Another study ${ }^{(26)}$, conducted with people in treatment for TB and HIV in a university hospital in Rio de Janeiro about the meanings of the comorbidity, revealed that both family support and the health professional's relationship with the patient, as well as faith and religion, are aspects that assist in greater adherence to treatment. In addition, for these individuals, living with the two treatments caused fear of side effects. They also had difficulty accepting and understanding the drug therapy and did not feel reassured by health professionals with regard to complaints about the medication. Many of them said they have abandoned treatment at some point and that they preferred to maintain secrecy about the comorbidity to not suffer discrimination from others. Thus, the Ministry of Health ${ }^{(27)}$ advises that during the management of TB/HIV co-infection, the bond formed between health professional and user is promoted, to ensure adherence to the treatment of both illnesses and due to the fact these individuals require constant evaluation and qualified listening for the different individual contexts, ensuring appropriate and effective approaches.

The analysis of the publications has shown that the Northeast region was the one with the greatest amount of studies, and that no studies from the South and Midwest regions were found. An epidemiological study conducted in the Northeast in 2014 ${ }^{(13)}$ indicated the region as the co-infection's endemic area, as despite the decrease in the incidence of TB, it featured higher incidence and mortality rates than the means of the whole country in 2011, revealing an association with the situation of poverty and the lack of structure of the region's public services.

About the clinical features observed in the literature, the pulmonary form of TB is the most common ${ }^{(28-29)}$, although one study showed prevalence of the mixed form (extrapulmonary + pulmonary $)^{(9)}$. Data from the Ministry of Health of $2016^{(30)}$ showed the prevalence of the pulmonary form in new $(78.4 \%)$ and retreatment $(85.2 \%)$ cases.

Alcohol was related to TB/HIV co-infection in some studies ${ }^{(11,20,22)}$. One of them, held in 2011, showed that the use of alcohol and illicit drugs hindered adherence to treatment, in addition to increasing the risk of adverse events and the loss of effectiveness of the medicines ${ }^{(25)}$.

The management of TB/HIV co-infection should be articulated fully and responsibility should be shared between the control programs of both infections. However, one of the goals of the Ministry of Health is that $90 \%$ of cases are submitted to DOT ${ }^{(2)}$.

In the analysis of the studies, the following DOT rates were found: $57 \%$ in the Northeast ${ }^{(12)}$ and from $34.6^{(17)}$ to $48 \%{ }^{(16)}$ in São Paulo, and $48.8 \%$ for self-administered treatment ${ }^{(17)}$ in Capão Redondo, municipality of São Paulo, which corroborates the literature, although the article ${ }^{(17)}$ that presents this data revealed lack of information in the database for $16.7 \%$ of coinfected patients with respect to this variable. One study ${ }^{(25)}$ identified that the high amount of drugs to be ingested, associated with the difficulty in understanding the intervals between doses, hindered adherence to treatment. The treatment outcome analysis' results were similar to the rates reported by the Ministry of Health. In 2016, the outcome of new cases of TB/HIV co-infection revealed $49.1 \%$ cure rate, $13.9 \%$ abandonment rate and $22.6 \%$ death rate, $18.2 \%$ by other causes and $4.4 \%$ by TB. The outcomes of the cases of coinfected patients in TB retreatment revealed, by comparison, low cure rate (35.8\%), high abandonment rate $(31.5 \%)$ and $18.2 \%$ death rate $(14.8 \%$ by other causes and $3.4 \%$ by TB). It is observed that co-infected patients in retreatment are cured $27 \%$ less often and abandon treatment twice as often than the new cases $^{(30)}$.

It is recommended by WHO that the cure rate is at least $85 \%$ lower and the abandonment rate $5 \%$ lower by 2020 . However, based on the 2016 data, Brazil falls short of reaching these goals ${ }^{(1)}$. A study in Brazil showed that a strategy to reduce the rates of unfavorable outcomes in cases of TB/HIV co-infection would be performing ART as early as possible in co-infected individuals ${ }^{(31)}$.

\section{Study limitations}

The limitations of the study may be related to the fact that not all researches analyzed the same socio-demographic factors and to the lack of information on some variables in the compulsory notification files, which may compromise the understanding of the epidemiological reality. Another limitation refers to the fact that the study did not include Brazilian studies on TB/HIV co-infection published in international journals.

\section{Contributions to the field of nursing}

It is believed that this study brings relevant contributions to the advancement of knowledge related to TB/HIV coinfection, for gathering, in a systematic review, the findings of researches conducted in a ten-year period. The knowledge of the demographic and health profile of TB/HIV co-infection in Brazil makes it possible to analyze the situation and rethink health practices aimed at the control of both diseases.

\section{CONCLUSION}

Given the goal of ascertaining the demographic and epidemiological profile of TB/HIV co-infection in the last ten years in the Brazilian context, it became apparent that the scientific literature about the co-infection's profile was similar to the one revealed by the analyzed variables, an exception being the death variable which revealed disparities when comparing the studies by region or national level, suggesting possible changes in the incidence of co-infection among females, and indicating the need for future investigations.

\section{FUNDING}

The realization of the research had the aid of a Scientific Initiation fellowship granted by Conselho Nacional de Desenvolvimento Científico e Tecnológico (CNPq), in the period from August 2017 to July 2018. 


\section{REFERENCES}

1. World Health Organization-WHO. Global Tuberculosis Report 2017 [Internet]. Geneva:WHO; 2017 [cited 2017 Dec 1]. Available from: http:// apps.who.int/iris/bitstream/10665/259366/1/9789241565516-eng.pdf?ua=1

2. Ministério da Saúde (BR). Brasil livre da tuberculose: plano nacional pelo fim da tuberculose como problema de saúde pública [Internet]. Brasília (DF); 2017 [cited 2017 Dec 1]. Available from: http://pesquisa.bvsalud.org/bvsms/resource/pt/mis-39341

3. World Health Organization-WHO. Global Tuberculosis Report 2015 [Internet]. Geneva: WHO; 2015 [cited 2017 Dec 2]. Available from: http:// apps.who.int/iris/bitstream/10665/191102/1/9789241565059_eng.pdf

4. Grangeiro A, Castanheira ER, Nemes MIB. The reemergence of the Aids epidemic in Brazil: challenges and perspectives to tackle the disease. Interface. 2015;19(52):5-6. doi:10.1590/1807-57622015.0038

5. Lima MS, Martins-Melo FR, Heukelbach J, Alencar CH, Boigny RN, Ramos-Júnior AN. Mortality related to tuberculosis-HIV/AIDS co-infection in Brazil, 2000-2011: epidemiological patterns and time trends. Cad Saúde Pública. 2016;32(10):1-11. doi: 10.1590/0102-311X00026715

6. Magnabosco GT, Lopes LM, Andrade REP, Brunello MEF, Monroe AA, Villa TCS. Tuberculosis control in people living with HIV/aids. Rev LatinoAm Enfermagem. 2016;24:e2798. doi: 10.1590/1518-8345.1187.2798

7. Prado TN, Miranda AE, Souza FM, Dias ES, Sousa LK, Arakaki-Sanchez D et al. Factors associated with tuberculosis by HIV status in the brazilian national surveillance system: a cross sectional study. BMC Infect Dis. 2014;14:415. doi: 10.1186/1471-2334-14-415

8. STROBE Statement: strengthening the reporting of observational studies in epidemiology [Internet]. 2009 [cited 2017 Nov 20]. Available from: https://www.strobe-statement.org/index.php?id=strobe-home.

9. Domingos MP, Caiaffa WT, Colosimo EA. Mortality, TB/HIV co-infection, and treatment dropout: predictors of tuberculosis prognosis in Recife, Pernambuco State, Brazil. Cad Saúde Pública. 2008;24(4):887-96. doi: 10.1590/S0102-311X2008000400020

10. Maruza M, Ximenes RAA, Lacerda HR. Treatment outcome and laboratory confirmation of tuberculosis diagnosis in patients with HIV/AIDS in Recife, Brazil. J Bras Pneumol. 2008;34(6):394-403. doi: 10.1590/\$1806-37132008000600010

11. Carvalho BM, Monteiro AJ, Pires-Neto RJ, Grangeiro TB, Frota CC. Factors related to HIV/Tuberculosis coinfection in a brazilian reference hospital. Braz J Infect Dis. 2008;12(4):281-6. doi: 10.1590/S1413-86702008000400005

12. Santos-Neto M, Silva FL, Sousa KR, Yamamura M, Popolin MP, Arcêncio RA. Clinical and epidemiological profile and prevalence of tuberculosis/HIV coinfection in a regional health district in the state of Maranhão, Brazil. J Bras Pneumol. 2012;38(6):724-32. doi: 10.1590/S1806-37132012000600007

13. Barbosa IR, Costa ICC. Estudo epidemiológico da coinfecção tuberculose-HIV no nordeste do Brasil. Rev Patol Trop. 2014;43(1):27-38. doi: 10.5216/rpt.v43i1.29369

14. Santos ML, Ponce MA, Vendramini SH, Villa TC, Santos NS, Wysocki AD, et al. The epidemiological dimension of TB/HIV co-infection. Rev Latino-Am Enfermagem 2009];17(5):683-8. doi: 10.1590/S0104-11692009000500014

15. Vendramini SH, Santos NS, Santos ML, Chiaravalloti-Neto F, Ponce MA, Gazetta CE, Villa TC, Ruffino-Netto A. Spatial analysis of tuberculosis/ HIV coinfection: its relation with socioeconomic levels in a city in south-eastern Brazil. Rev Soc Bras Med Trop. 2010 [cited 2017 Nov 28];43(5):536-41. doi: 10.1590/S0037-86822010000500013

16. Brunello ME, Chiaravalloti-Neto F, Arcêncio RA, Andrade RL, Magnabosco GT, Villa TC. Areas of vulnerability to HIV/TB co-infection in Southeastern Brazil. Rev Saúde Pública. 2011;45(3):556-63. doi: 10.1590/S0034-89102011005000018

17. Hino P, Takahashi RF, Bertolozzi MR, Egry EY. Coinfection of Tuberculosis/Human Immunodeficiency Virus in an Administrative District in the City of São Paulo. Acta Paul Enferm. 2012;25(5):755-61. doi: 10.1590/S0103-21002012000500017

18. Rodrigues-Júnior AL, Ruffino-Netto A, de Castilho EA. Spatial distribution of the human development index, HIV infection and AIDSTuberculosis comorbidity: Brazil, 1982-2007. Rev Bras Epidemiol. 2014 17(Suppl DSS):204-15. doi: 10.1590/1809-4503201400060017

19. Gaspar RS, Nunes N, Nunes M, Rodrigues VP. Temporal analysis of reported cases of tuberculosis and of tuberculosis-HIV coinfection in Brazil between 2002 and 2012. J Bras Pneumol. 2016;42(6):416-22. doi: 10.1590/s1806-37562016000000054

20. Prado TN, Rajan JV, Miranda AE, Dias ED, Cosme LB, Possuelo LG, et al. Clinical and epidemiological characteristics associated with unfavorable tuberculosis treatment outcomes in TB-HIV co-infected patients in Brazil: a hierarchical polytomous analysis. Braz J Infect Dis. 2017 21(2):162-70. doi: 10.1016/j.bjid.2016.11.006

21. Magno EDS, Saraceni V, Souza AB, Magno RDS, Saraiva MDGG, Buhrer-Sékula S. Factors associated with TB/HIV coinfection: evidence from notification data in the state of Amazonas, Brazil, 2001-2012. Cad Saúde Pública. 2017;33(5):e00019315. doi: 10.1590/0102-311x00019315

22. Oliveira NF, Gonçalves MJ. Social and environmental factors associated with the hospitalization of tuberculosis patients. Rev Latino-Am Enfermagem. 2013; 21(2):507-14. doi: 10.1590/S0104-11692013000200006

23. Ministério da Saúde (BR). Boletim Epidemiológico: HIV AIDS 2017 [Internet]. 2017 [cited 2018 Jan 4]. Available from: http://www.aids.gov. br/pt-br/pub/2017/boletim-epidemiologico-hivaids-2017

24. Ferreira Jr S, Francisco PMSB, Nogueira PA. Profile of transvestites and transgender women: tuberculosis and HIV/AIDS in the city of São Paulo. Rev Panam Salud Publica [Internet]. 2016 [cited 2018 Jan 4];40(6):410-17. Available from: https://www.scielosp.org/article/rpsp/2016. v40n6/410-417/ 
25. Sousa Filho MP, Luna IT, da Silva KL, Pinheiro PNC. Patients living with HIV/AIDS and co-infection by tuberculosis: difficulties associated with treatment compliance or dropout. Rev Gaucha Enferm. 2012;33(2):139-45. doi: 10.1590/S1983-14472012000200020

26. Silva JB, Cardoso GCP, Netto AR, Kritski AL. Os significados da comorbidade para os pacientes vivendo com TB/HIV: repercussões no tratamento. Physis. 2015 [;25(1):209-29. doi: 10.1590/S0103-73312015000100012

27. Ministério da Saúde (BR). Recomendações para o manejo da coinfecção TB-HIV em serviços de atenção especializada a pessoas vivendo com HIV/AIDS. Brasília (DF) [Internet]: 2013 [cited 2018 Jan 5]. Available from: http://www.saude.sp.gov.br/resources/crt/publicacoes/ publicacoes-download/guiabasicotbhiv.pdf

28. Marques M, Ruffino-Netto A, Marques AMC, Andrade SMO, Silva BAK, Pontes ERJC. Pulmonary tuberculosis among residents of municipalities in Mato Grosso do Sul State, Brazil, bordering on Paraguay and Bolivia. Cad Saúde Pública. 2014; 30(12):2631-42. doi: 10.1590/0102-311x00191513

29. Perrechi MCT, Ribeiro SA. Outcomes of tuberculosis treatment among inpatients and outpatients in the city of São Paulo, Brazil. J Bras Pneumol. 2011;37(6):783-90. doi: 10.1590/S1806-37132011000600012

30. Ministério da Saúde (BR). Boletim Epidemiológico: Coinfecção TB-HIV no Brasil: panorama epidemiológico e atividades colaborativas Brasília (DF) [Internet].:; 2017 [cited 2018 Jan 5]. Available from: http://www.aids.gov.br/pt-br/pub/2017/ coinfeccao-tb-hiv-no-brasil-panorama-epidemiologico-e-atividades-colaborativas-2017

31. Torrens A, Bartholomay P, Silva S, Khogali M, Verdonck K, Bissel K. HIV testing, antiretroviral therapy, and treatment outcomes in new cases of tuberculosis in Brazil, 2011. Rev Panam Salud Publica [Internet]. 2016 [cited 2018 Jan 10];39(1):26-31. Available from: https://scielosp.org/ article/rpsp/2016.v39n1/26-31/ 